\title{
Effect of heat treatment of human milk on absorption of nitrogen, fat, sodium, calcium, and phosphorus by preterm infants
}

\author{
S. WILLIAMSON, E. FINUCANE, H. ELLIS, AND H. R. GAMSU \\ From the Department of Child Health, King's College Hospital Medical School, London
}

SUMMARY Seven very low birthweight $(<1.3 \mathrm{~kg})$ preterm infants, aged between 3 and 6 weeks were fed raw, pasteurised, and boiled human milk for 3 consecutive weeks. Serial metabolic balance techniques were used to assess the absorption and retention of calcium, phosphorous, sodium, and nitrogen, and the absorption of fat. Fat absorption was reduced by approximately one-third when raw milk was heated. It is suggested that the improved fat absorption from the raw milk may be related to the preservation of milk lipases. A reduction in the amount of $\mathrm{N}$ retained was also noted when the infants were fed boiled milk. There were no obvious differences in the absorption of $\mathrm{N}$ or the absorption and retention of $\mathrm{Ca}, \mathrm{P}$, and $\mathrm{Na}$ between the three milks. All infants gained weight most rapidly during the week in which they were fed raw milk. The mean weight gain during this time was approximately one-third greater than that during similar periods when pasteurised or boiled milk was administered.

The ideal nutrition for the very low birthweight $(<1.5 \mathrm{~kg})$ preterm infant has yet to be defined. Once premature delivery has occurred it is difficult to achieve the weight gain and physical proportions of a fetus of corresponding postconceptual age. Using milk for this purpose is made difficult by several factors. Large volumes of milk are poorly tolerated, intestinal absorption is limited, and there are restrictions on the renal excretion of a solute load. Human milk, although resulting in favourable calcium and fat absorption compared with many modified cows' milk preparations (Zoula et al., 1966; Shaw, 1976), seems to be deficient in at least protein, calcium, some vitamins, and iron (Stearns, 1939; Davies, 1977; Fomon et al., 1977). However, there is at present little evidence to show that other milks available in this country are preferable to breast milk for such infants.

Many of the factors that influence paediatricians to recommend breast feeding for term infants (Addy, 1976), are of equal if not greater importance in the preterm infant. However, unlike its term counterpart the preterm infant usually receives human milk only after it has been 'sterilised' by some form of heat treatment. It has not yet been

Received 14 December 1977 established whether heating human milk affects the nutrition of the infant. This study was designed to investigate this. To discover how breast milk is commonly prepared for use we conducted a survey of 38 neonatal units. 30 units were found to heat at least a part of their breast milk supply before feeding it; 4 used a form of pasteurisation (usually $63^{\circ} \mathrm{C}$ for half-an-hour); in the remainder, the milk was boiled. It was therefore considered relevant to compare raw (unheated), pasteurised, and boiled human milk.

\section{Patients and methods}

Each of the 7 infants chosen as subjects for the investigation had been admitted to an intensive care unit. Each weighed $1.3 \mathrm{~kg}$ or less at birth and had a gestational age of 33 weeks or less (Table 1). Gestational ages were assessed from the date of the last menstrual period, if this was accurately known; otherwise the assessment was based on a paediatric examination (Dubowitz et al., 1970). Case 7 developed an aspiration pneumonia requiring treatment with antibiotics and intermittent positive pressure ventilation at 3 weeks of age, one week before the start of the study. The remainder had had no serious illness before the study. Six infants 
Table 1 Details at birth of infants studied and order in which milks were fed

\begin{tabular}{|c|c|c|c|c|c|}
\hline Case no. & Sex & $\begin{array}{l}\text { Birthweight } \\
(\mathrm{kg})\end{array}$ & $\begin{array}{l}\text { Gestational age } \\
\text { (weeks) }\end{array}$ & $\begin{array}{l}\text { Birthweight } \\
\text { centile* }\end{array}$ & Milk order \\
\hline $\begin{array}{l}1 \\
2 \\
3 \\
4 \\
5 \\
6 \\
7\end{array}$ & $\begin{array}{l}\mathbf{F} \\
\mathbf{F} \\
\mathbf{M} \\
\mathbf{F} \\
\mathbf{M} \\
\mathbf{F} \\
\mathbf{M}\end{array}$ & $\begin{array}{l}1 \cdot 11 \\
1 \cdot 3 \\
1 \cdot 17 \\
1 \cdot 24 \\
1 \cdot 00 \\
1 \cdot 06 \\
1 \cdot 06\end{array}$ & $\begin{array}{l}30 \\
32 \\
30 \\
30 \\
27 \\
33 \\
30\end{array}$ & $\begin{array}{r}10 \text { th } \\
10 \text { th } \\
10 \text { th } \\
25 \text { th } \\
50 \text { th } \\
<10 \text { th } \\
10 \text { th }\end{array}$ & $\begin{array}{l}\mathbf{B} / \mathbf{R} / \mathbf{P} \\
\mathbf{P} / \mathbf{R} / \mathbf{B} \\
\mathbf{B} / \mathbf{P} / \mathbf{R} \\
\mathbf{R} / \mathbf{B} / \mathbf{P} \\
\mathbf{R} / \mathbf{P} / \mathbf{B} \\
\mathbf{P} / \mathbf{B} / \mathbf{R} \\
\mathbf{R} / \mathbf{P} / \mathbf{B}\end{array}$ \\
\hline
\end{tabular}

were patients in the neonatal intensive care unit at King's College Hospital, a seventh was studied in a similar unit at St Thomas's Hospital.

\section{Methods}

Design of the study. The study was designed so as to eliminate, as far as possible, differences in absorption and retention related to the differences in size, maturity, and postnatal age of the infants. Each of the three milks-raw, pasteurised, and boiledwas fed to each infant for one of three consecutive weeks. Each infant (except Case 7) received the three milks in a different order to take into account the six possible sequences of the three milks. The infants were weighed daily and metabolic balance studies were performed during the last 2 days of each week. The order in which the milks were fed to Case 7 was duplicated by that of Case 5 as it was considered that the results obtained from Case 7 could well have been affected by the infant's poor clinical condition shortly before the study (the data from Case 7 are listed in Table 9 but are not included in the statistical analyses).

Each infant was fed boiled human milk from birth, as at the time of the study this was the form of milk routinely used in our unit. Each study was started when the infant weighed approximately $1.3 \mathrm{~kg}$ and had established a consistent gain in weight. This varied between 21 and 42 days. A summary of the infants at the time of the balance studies is shown in Table 2. There were no significant differences in the infants' weights, ages, or milk intakes between the three groups. The order in which the milks were fed is shown in Table 1.

Milk. Mature human milk was collected by a sterile technique from hepatitis B surface antigen-negative donors. Only milks with a total bacterial count $<2500$ aerobic bacteria $/ \mathrm{ml}$ were used. Milk containing Staphylococcus aureus, Enterobacteriaceae, or Pseudomonas aeruginosa was excluded.

A pool of such milk, produced by several donors, was collected and used for all 3 balance studies for each infant. One-third of the pool was left in the raw state, one-third was pasteurised $\left(63^{\circ} \mathrm{C}\right.$ for half-an-hour), and one-third was brought to boiling point and then rapidly cooled. Thus each individual infant's balance studies used only one pool of milk but a different pool was used for each infant. The milk fed to the infants during the week before each study was human milk, processed in the same way as the balance study milk, but not from the same pool. All balance study milks were stored at $-18^{\circ} \mathrm{C}$ and defrosted immediately before feeding.

The volumes of milk given were calculated from the infant's postnatal age and weight, and modified depending upon its tolerance of volumes previously fed. The composition of the milks used in the 21 balance studies is shown in Table 3. All infants received additional vitamin D $400 \mathrm{IU} /$ day in the form of a multivitamin aqueous solution (Abidec: Parke-Davis), iron $25 \mathrm{mg} /$ day (Plesmet: Napp Laboratories), and folic acid $1 \mathrm{mg} /$ day.

Table 2 Details of infants at the time of balance studies (Cases 1-6 inclusive)

\begin{tabular}{|c|c|c|c|c|c|}
\hline Milk & $\begin{array}{l}\text { Weight } \\
(k g)\end{array}$ & $\begin{array}{l}\text { Age } \\
\text { (days) }\end{array}$ & $\begin{array}{l}\text { Intake } \\
\text { (ml/kg per day) }\end{array}$ & $\begin{array}{l}\text { Urine output } \\
(\mathrm{ml} / \mathrm{kg} \text { per day) }\end{array}$ & $\begin{array}{l}\text { Faecal output } \\
\text { (g/kg per day) }\end{array}$ \\
\hline \multicolumn{6}{|l|}{ Raw } \\
\hline $\begin{array}{c}\text { Mean } \\
\text { Range } \\
\text { Pasteurised }\end{array}$ & $\begin{array}{l}1 \cdot 54 \\
1 \cdot 39-1 \cdot 67\end{array}$ & $\begin{array}{l}35 \\
23-42\end{array}$ & $\begin{array}{l}265 \\
231-362\end{array}$ & $\begin{array}{l}163 \cdot 6 \\
138 \cdot 2-205 \cdot 7\end{array}$ & $\begin{array}{l}14 \cdot 82 \\
4 \cdot 49-30 \cdot 47\end{array}$ \\
\hline $\begin{array}{l}\text { Mean } \\
\text { Range } \\
\text { Boiled }\end{array}$ & $\begin{array}{l}1 \cdot 50 \\
1 \cdot 25-1 \cdot 86\end{array}$ & $\begin{array}{l}35 \\
21-49\end{array}$ & $\begin{array}{l}255 \\
224-322\end{array}$ & $\begin{array}{l}162 \cdot 0 \\
130 \cdot 5-237 \cdot 7\end{array}$ & $\begin{array}{l}18 \cdot 34 \\
12 \cdot 0-27 \cdot 4\end{array}$ \\
\hline $\begin{array}{l}\text { Mean } \\
\text { Range }\end{array}$ & $\begin{array}{l}1 \cdot 52 \\
1 \cdot 34-1 \cdot 73\end{array}$ & $\begin{array}{l}35 \\
28-56\end{array}$ & $\begin{array}{l}248 \\
214-351\end{array}$ & $\begin{array}{l}167 \cdot 8 \\
136 \cdot 4-233 \cdot 9\end{array}$ & $\begin{array}{l}17 \cdot 09 \\
9 \cdot 43-28 \cdot 16\end{array}$ \\
\hline
\end{tabular}


Table 3 Milk analyses

\begin{tabular}{|c|c|c|c|c|c|c|c|}
\hline \multirow{2}{*}{$\begin{array}{l}\text { Milk } \\
\text { (mean) }\end{array}$} & \multirow{2}{*}{$\begin{array}{l}\text { Fat } \\
(g / l)\end{array}$} & \multirow{2}{*}{$\begin{array}{l}\% \text { free } \\
\text { fatty acids }\end{array}$} & \multicolumn{4}{|l|}{ mmol/l } & \multirow{2}{*}{$\begin{array}{l}\text { Osmolality } \\
(\mathrm{mOsm} / \mathrm{kg})\end{array}$} \\
\hline & & & Nitrogen & Sodium & Calcium & Phosphorus & \\
\hline Raw & $29 \cdot 67$ & $16 \cdot 0$ & $\begin{array}{l}119 \\
(166 \cdot 7)\end{array}$ & $\begin{array}{l}6 \cdot 97 \\
(16 \cdot 0)\end{array}$ & $\begin{array}{l}7 \cdot 34 \\
(29 \cdot 4)\end{array}$ & $\begin{array}{l}4 \cdot 05 \\
(12 \cdot 5)\end{array}$ & 286 \\
\hline Pasteurised & $30 \cdot 9$ & $12 \cdot 6$ & $\begin{array}{l}122 \\
(170 \cdot 9)\end{array}$ & $\begin{array}{l}6 \cdot 78 \\
(15 \cdot 6)\end{array}$ & $\begin{array}{l}7 \cdot 36 \\
(29 \cdot 5)\end{array}$ & $\begin{array}{l}4 \cdot 02 \\
(12 \cdot 5)\end{array}$ & 290 \\
\hline Boiled & $29 \cdot 51$ & $12 \cdot 6$ & $\begin{array}{l}125 \\
(175 \cdot 1)\end{array}$ & $\begin{array}{l}7 \cdot 23 \\
(16 \cdot 6)\end{array}$ & $\begin{array}{l}7 \cdot 43 \\
(29 \cdot 8)\end{array}$ & $\begin{array}{l}4 \cdot 15 \\
(12 \cdot 9)\end{array}$ & 301 \\
\hline $\begin{array}{l}\text { SED } \\
F(2,8)\end{array}$ & $\begin{array}{l}0.745 \\
\text { NS }\end{array}$ & $\begin{array}{l}0.96 \\
8.289 \\
P<0.01\end{array}$ & $\begin{array}{l}0.27 \\
\text { NS }\end{array}$ & $\begin{array}{l}0.24 \\
\text { NS }\end{array}$ & $\begin{array}{l}0.079 \\
\text { NS }\end{array}$ & $\begin{array}{l}0.049 \\
\text { NS }\end{array}$ & $\begin{array}{l}7 \cdot 03 \\
\text { NS }\end{array}$ \\
\hline
\end{tabular}

NS = no significant difference; SED = standard error of difference between any pair of means.

Figures in brackets are $\mathrm{mg} / 100 \mathrm{ml}$.

Metabolic balance techniques. Informed consent was obtained from all parents. The infants were nursed in incubators at an ambient temperature determined by their age and weight; stool and urine collections were supervised throughout the study by trained staff and medical students. On the first day of each 48-hour balance study the feeds were measured into sterile polycarbonate feeding bottles which were then weighed. An aliquot of the milk for each balance study was then taken for analysis. All milk was given via $20 \mathrm{ml}$ disposable syringes attached to polyethylene nasogastric feeding tubes ( 5 FG). At the end of each feed the feeding bottles were reweighed to determine the volume fed. The specific gravity of each milk sample was measured to enable determination of the volume from the weight.

During the processing and feeding of the milk, creaming of the milk fat occurs which is then liable to adhere to the sides of the syringe. The syringes were therefore saved, the milk remaining in them analysed, and this weight of fat subtracted from the infant's intake. A record was kept of any spillage, and regurgitated milk was collected on large nylon bibs, backed with polyethylene and spread under and around the infant's head. Both spillage and regurgitation were rare. Feeds were given 3-hourly to all infants except Case 4 who was fed every 2 hours.

The stool collection was delineated by two $25 \mathrm{mg}$ carmine markers. The first was given immediately before the first of the balance feeds, the second after the last of the balance feeds at the end of the 48-hour balance period. Stools were collected from (and including) the first specimen containing carmine until (and excluding) the specimen containing carmine from the second marker. Preweighed, calcium-free cellophane nappy liners were used to collect the stools. A V-shaped cleft cut into the mattress between the infant's legs allowed the stool to drop on to the nappy liner. Padded cotton restraints were looped around the infant's thighs, thus maintaining a position of abduction. Soiled nappies were immediately stored at $-18^{\circ} \mathrm{C}$ until they were reweighed and the stool analysed.

Urine was collected during the 48-hour balance period from the baby girls by means of self-adhesive 24-hour urine collecting bags. The boys' urine was collected via acid-washed thin rubber tubing. All urine samples were removed immediately after voiding and stored at $-18^{\circ} \mathrm{C}$.

There were no significant differences in the amounts of urine or stool excreted between the three groups (Table 2).

Analytical methods. The stool was scraped from the soiled nappy liners which were then washed twice in hot $\left(70^{\circ} \mathrm{C}\right) 0.1 \mathrm{M} \mathrm{HCl}$. The stools and washings were homogenised for $\mathbf{3 0}$ seconds and sonicated for 10 minutes (Bliss et al., 1971). Further $0.1 \mathrm{M} \mathrm{HCl}$ was then added so that the final stool homogenate contained 5-7 $\mathrm{g}$ of stool $/ 100 \mathrm{ml}$.

The syringes used for feeding the infants were rinsed with $96 \%$ ethyl alcohol plus $0.4 \%$ amyl alcohol. These washings, the stool homogenates (in duplicate), and aliquots of the balance study milks were analysed for total fat and free fatty acids by the method of Van de Kamer et al. (1949).

The $\mathrm{Na}, \mathrm{Ca}$, and $\mathrm{P}$ analyses were carried out in duplicate using $1 \mathrm{ml}$ aliquots of the milks and stool homogenates. These were initially dried at $90^{\circ} \mathrm{C}$ then ashed in a muffle furnace for 18 hours at $480^{\circ} \mathrm{C}$. The ash was dissolved in dilute $\mathrm{HCl}$ and then further diluted with either deionised water or $0.5 \%$ lanthanum chloride solution for analysis of $\mathrm{Na}$ and $\mathrm{Ca}$ respectively. $\mathrm{Na}$ was determined by flame emission spectrophotometry and $\mathrm{Ca}$ by atomic absorption spectrophotometry, using a Pye Unicam SP 90 atomic absorption spectrophotometer. Urine samples were analysed similarly for $\mathrm{Na}$ and $\mathrm{Ca}$ but without ashing beforehand. The $P$ in the ashed stools and milk samples was determined by a colorimetric method using a molybdate/vanadate reagent. Urinary $\mathbf{P}$ was estimated by the method of Delsal and Manhouri, described by Wootton (1964). 
Table 4 Fat balance studies

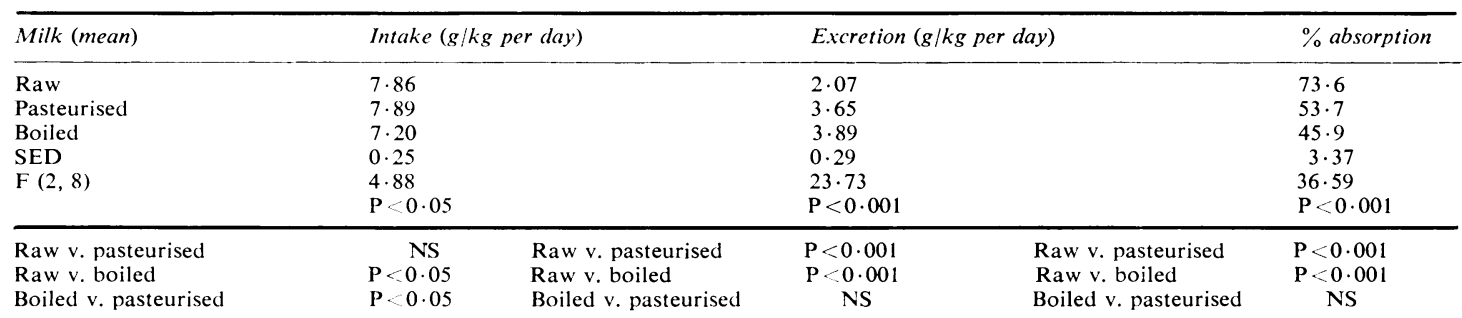

Total $\mathrm{N}$ in homogenates of the stool and also in milk and urine samples was determined by a modified micro-Kjeldahl method (O'Brien et al., 1968). Milk osmolalities were measured on a Fiske osmometer. Fat determinations were initially carried out on the bib washings but the amounts obtained were negligible and the results were not included in the calculations.

\section{Results}

In all balance studies absorption signifies the difference between intake and faecal excretion; retention the differences between intake and total excretion (faeces plus urine). Analyses of variance was carried out for each variate and then an $F$ test applied to determine significant differences between the 3 types of milk. Any difference with a significance equal to or greater than the $5 \%$ level was also assigned a $P$ value. When computing the percentage of absorption and retention of the various nutrients, a weighted analysis of variance was carried out, using the appropriate intake as the weighting factor.

Fat balance studies. Details of the fat balance studies are shown in Table 4 . The fat intake during the boiled milk periods was significantly lower than with the other milks. Fat losses adhering to the sides of the feeding syringes made a very small contribution to this difference. A mean of $0.426 \mathrm{~g}$ fat in the 48 hours of the boiled milk balance study compared with $0.079 \mathrm{~g}$ and $0.198 \mathrm{~g}$ in the balance study periods of the raw and pasteurised milks respectively. Each of the 6 infants demonstrated impaired fat absorption from the heated milks compared with the raw (Figure). The mean fat absorptions from the pasteurised and boiled milks were $72.9 \%$ and $62.4 \%$ respectively of the mean fat absorption resulting from the raw milk. The poorest fat absorption (a mean of $41 \%$ from the three milks) was noted from Case 4 in whom the fat intake (a mean of $9 \cdot 88 \mathrm{~g} / \mathrm{kg}$ per day) was also the greatest. The group as a whole demonstrated an inverse correlation between fat intake and percentage fat absorption (correlation coefficient $-0 \cdot 46$ ).

The percentage of faecal fat analysed as free fatty acids was greater $(P<0.01)$ in the stools resulting from the raw milk feeds. A mean of $81 \cdot 9 \%$ for the raw milk, $69 \cdot 7 \%$ for the pasteurised, and $712 \%$ for the boiled milks, standard error of difference (SED) $2 \cdot 5 \%$.

Nitrogen balance studies. The mean $\mathrm{N}$ intake from the three milks was not significantly different (Table 5) nor was the percentage of $\mathrm{N}$ absorbed. However, 4 of the 6 infants (Cases 1, 2, 3, and 6)

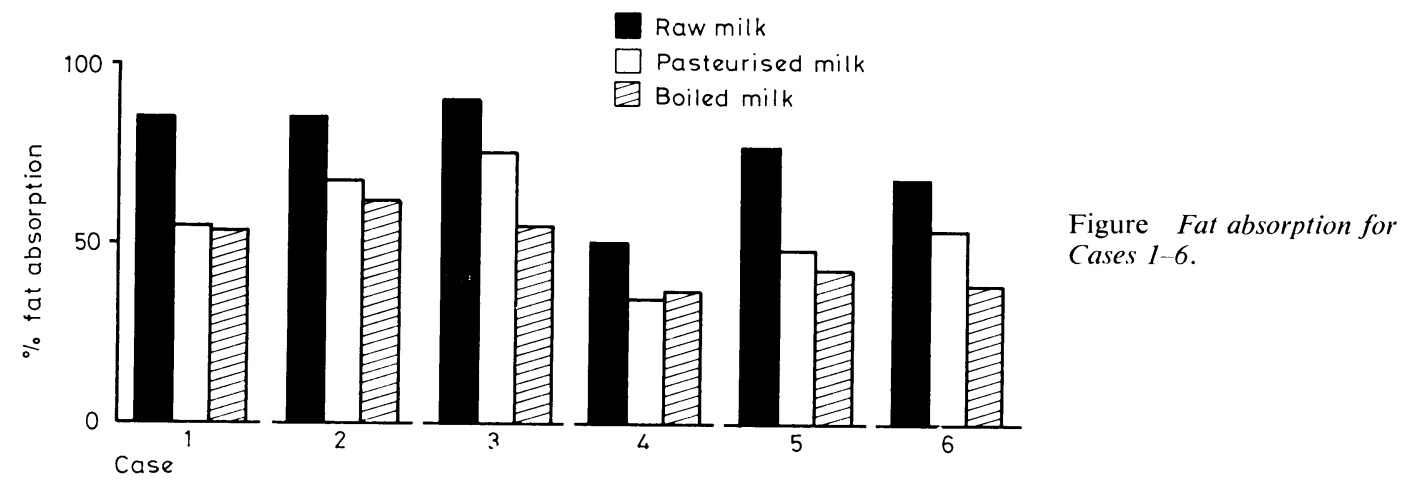


Table 5 Nitrogen balance studies

\begin{tabular}{|c|c|c|c|c|c|}
\hline \multirow[t]{3}{*}{ Milk (mean) } & \multicolumn{3}{|c|}{ mmol/kg per day } & \multirow[t]{3}{*}{$\%$ absorption } & \multirow[t]{3}{*}{$\%$ retention } \\
\hline & \multirow[t]{2}{*}{ Intake } & \multicolumn{2}{|c|}{ Excretion } & & \\
\hline & & Faeces & Urine & & \\
\hline Raw & $\begin{array}{l}31 \cdot 59 \\
(442 \cdot 5)\end{array}$ & $\begin{array}{l}5 \cdot 58 \\
(78 \cdot 2)\end{array}$ & $\begin{array}{l}7 \cdot 64 \\
(107)\end{array}$ & $82 \cdot 3$ & $58 \cdot 1$ \\
\hline Pasteurised & $\begin{array}{l}31 \cdot 27 \\
(438)\end{array}$ & $\begin{array}{l}5 \cdot 98 \\
(83 \cdot 8)\end{array}$ & $\begin{array}{l}7 \cdot 76 \\
(108 \cdot 7)\end{array}$ & $80 \cdot 9$ & $56 \cdot 1$ \\
\hline Boiled & $\begin{array}{l}31 \cdot 07 \\
(435 \cdot 2)\end{array}$ & $\begin{array}{l}5 \cdot 74 \\
(80 \cdot 4)\end{array}$ & $\begin{array}{l}9 \cdot 28 \\
(130)\end{array}$ & $81 \cdot 5$ & $51 \cdot 5$ \\
\hline $\begin{array}{l}\text { SED } \\
\text { F }(2,8)\end{array}$ & $\begin{array}{l}1 \cdot 03 \\
\text { NS }\end{array}$ & $\begin{array}{l}0.29 \\
\text { NS }\end{array}$ & $\begin{array}{l}0.86 \\
\text { NS }\end{array}$ & $\begin{array}{l}1 \cdot 26 \\
\mathrm{NS}\end{array}$ & $\begin{array}{l}3 \cdot 10 \\
\text { NS }\end{array}$ \\
\hline
\end{tabular}

Figures in brackets are $\mathrm{mg} / \mathrm{kg}$ per day.

demonstrated improved N-retention when fed raw milk. Although $\mathrm{N}$-retention in the group as a whole seemed better when the infants were fed raw or pasteurised milk, there was no significant difference between those values and those resulting from the feeding of boiled milk.

Calcium, phosphorus, and sodium balance studies. No significant difference was found between the three milks in the absorption and retention of $\mathrm{Ca}$, $\mathrm{P}$, or $\mathrm{Na}$ (Tables $6,7,8$ ). The data for Case 7 are given in Table 9 (but these were not included in the statistical analyses). The absorption of $\mathrm{Na}$ and $\mathbf{P}$ was uniformly good over a relatively narrow range, while that of $\mathrm{Ca}$ varied widely, mainly because Case 4 had a large $\mathrm{Ca}$ intake but a low percentage of absorption. $\mathrm{Na}$ was the only constituent investigated the absorption and retention of which correlated significantly with postnatal age for the 3 weeks of the study. The correlation coefficients were 0.512 for $\mathrm{Na}$ absorption and 0.478 for $\mathrm{Na}$ retention. The absorption and retention of $\mathrm{Ca}$ (correlation coefficients 0.409 and 0.407 respectively) failed to achieve a similar significance.

Carmine transit times. The mean transit times were $14 \cdot 6$ hours for the raw milk, $12 \cdot 1$ hours for the pasteurised milk, and $11 \cdot 3$ hours for the boiled milk, SED $2 \cdot 6$ hours. These differences were not significant.

Weight gain and clinical course. Each infant had a greater weight gain during the week it was fed raw milk. The mean weight gains while they received raw, pasteurised, and boiled milks were $9 \cdot 24$, $6 \cdot 34$, and $6.63 \mathrm{~g} / 100 \mathrm{ml}$ milk respectively (SED $0.78, \mathrm{P}<0.01$ ).

None of the infants developed serious illness during the period of the balance studies. At 8 weeks of age Case 5 was noted to have craniotabes. $X$-rays of the skull and wrist showed osteoporosis, serum alkaline phosphatase was elevated, serum $\mathrm{Ca}$ and $P$ were normal. A second infant (Case 4) also had both radiological and biochemical evidence of rickets at age 3 months.

\section{Discussion}

In view of its content of functioning white cells and active enzymes, human milk has aptly been described as a living fluid (Jelliffe, 1975). However, there have been few studies on the nutritional consequences of 'killing' it by heat treatment and the reported results have been conflicting. Our

Table 6 Calcium balance studies

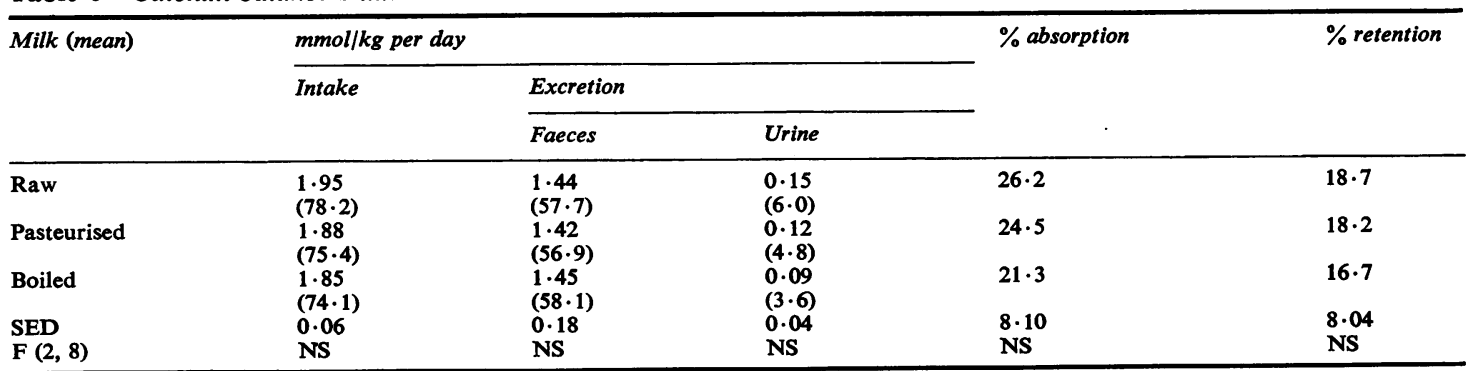

Figures in brackets are in $\mathrm{mg} / \mathrm{kg}$ per day. 
Table 7 Sodium balance studies

\begin{tabular}{|c|c|c|c|c|c|}
\hline \multirow[t]{3}{*}{ Milk (mean) } & \multicolumn{3}{|c|}{ mmol/kg per day } & \multirow[t]{3}{*}{$\%$ absorption } & \multirow[t]{3}{*}{$\%$ retention } \\
\hline & \multirow[t]{2}{*}{ Intake } & \multicolumn{2}{|c|}{ Excretion } & & \\
\hline & & Faeces & Urine & & \\
\hline Raw & $\begin{array}{l}1 \cdot 83 \\
(42 \cdot 1)\end{array}$ & $\begin{array}{l}0 \cdot 21 \\
(4 \cdot 8)\end{array}$ & $\begin{array}{l}0 \cdot 82 \\
(18 \cdot 9)\end{array}$ & $88 \cdot 4$ & $43 \cdot 5$ \\
\hline Pasteurised & $\begin{array}{l}1 \cdot 72 \\
(39 \cdot 5)\end{array}$ & $\begin{array}{l}0 \cdot 29 \\
(6 \cdot 7)\end{array}$ & $\begin{array}{l}0.65 \\
(14 \cdot 9)\end{array}$ & $83 \cdot 1$ & $45 \cdot 6$ \\
\hline Boiled & $\begin{array}{l}1 \cdot 78 \\
(40 \cdot 7)\end{array}$ & $\begin{array}{l}0.30 \\
(6 \cdot 9)\end{array}$ & $\begin{array}{l}0.68 \\
(15 \cdot 6)\end{array}$ & $83 \cdot 4$ & $45 \cdot 1$ \\
\hline $\begin{array}{l}\text { SED } \\
\text { F }(2,8)\end{array}$ & $\begin{array}{l}0.08 \\
\text { NS }\end{array}$ & $\begin{array}{l}0.06 \\
\text { NS }\end{array}$ & $\begin{array}{l}0.14 \\
\mathrm{NS}\end{array}$ & $\begin{array}{l}4.40 \\
\mathrm{NS}\end{array}$ & $\begin{array}{l}8.41 \\
\text { NS }\end{array}$ \\
\hline
\end{tabular}

Figures in brackets are $\mathrm{mg} / \mathrm{kg}$ per day.

Table 8 Phosphorus balance studies

\begin{tabular}{|c|c|c|c|c|c|}
\hline \multirow[t]{3}{*}{ Milk (mean) } & \multicolumn{3}{|c|}{ mmol/kg per day } & \multirow[t]{3}{*}{$\%$ absorption } & \multirow[t]{3}{*}{$\%$ retention } \\
\hline & \multirow[t]{2}{*}{ Intake } & \multicolumn{2}{|c|}{ Excretion } & & \\
\hline & & Faeces & Urine & & \\
\hline Raw & $\begin{array}{l}1 \cdot 07 \\
(33 \cdot 1)\end{array}$ & $\begin{array}{l}0 \cdot 12 \\
(3 \cdot 7)\end{array}$ & $\begin{array}{l}0.31 \\
(9.6)\end{array}$ & $88 \cdot 6$ & $59 \cdot 5$ \\
\hline Pasteurised & $\begin{array}{l}1 \cdot 02 \\
(31 \cdot 6)\end{array}$ & $\begin{array}{l}0.13 \\
(4 \cdot 0)\end{array}$ & $\begin{array}{l}0.19 \\
(5 \cdot 9)\end{array}$ & $87 \cdot 4$ & 68.9 \\
\hline Boiled & $\begin{array}{l}1 \cdot 03 \\
(31 \cdot 9)\end{array}$ & $\begin{array}{l}0 \cdot 14 \\
(4 \cdot 3)\end{array}$ & $\begin{array}{l}0 \cdot 21 \\
(6 \cdot 5)\end{array}$ & $86 \cdot 0$ & $66 \cdot 0$ \\
\hline SED & 0.034 & 0.043 & 0.099 & $4 \cdot 21$ & $8 \cdot 81$ \\
\hline$F(2,8)$ & NS & NS & NS & NS & NS \\
\hline
\end{tabular}

Figures in brackets are $\mathrm{mg} / \mathrm{kg}$ per day.

Table 9 Details of case 7

\begin{tabular}{|c|c|c|c|c|c|c|c|c|c|}
\hline \multirow[t]{2}{*}{ Milk } & \multirow{2}{*}{$\frac{\text { Fat }}{(\% \text { absorption })}$} & \multicolumn{2}{|l|}{ Calcium } & \multicolumn{2}{|l|}{ Phosphorous } & \multicolumn{2}{|l|}{ Sodium } & \multicolumn{2}{|l|}{ Nitrogen } \\
\hline & & $\%$ absorption & $\%$ retention & $\%$ absorption & $\%$ retention & $\%$ absorption & $\%$ retention & $\%$ absorption & $\%$ retention \\
\hline $\begin{array}{l}\text { Raw } \\
\text { Pasteurised } \\
\text { Boiled }\end{array}$ & $\begin{array}{l}50 \cdot 5 \\
56 \cdot 5 \\
49 \cdot 8\end{array}$ & $\begin{array}{l}12 \cdot 4 \\
23 \cdot 6 \\
16 \cdot 1\end{array}$ & $\begin{array}{r}6 \cdot 5 \\
18 \cdot 4 \\
12 \cdot 6\end{array}$ & $\begin{array}{l}86 \cdot 0 \\
88 \cdot 9 \\
86 \cdot 7\end{array}$ & $\begin{array}{l}84 \cdot 9 \\
87 \cdot 8 \\
85 \cdot 7\end{array}$ & $\begin{array}{l}87 \cdot 2 \\
83 \cdot 8 \\
83 \cdot 4\end{array}$ & $\begin{array}{l}56 \cdot 0 \\
45 \cdot 9 \\
59 \cdot 6\end{array}$ & $\begin{array}{l}79 \cdot 9 \\
82 \cdot 4 \\
83 \cdot 6\end{array}$ & $\begin{array}{l}58 \cdot 3 \\
60 \cdot 6 \\
60 \cdot 5\end{array}$ \\
\hline
\end{tabular}

initial survey shows that the use of heat-treated milk is common and indicates the practical importance of determining whether any loss of nutritional value has resulted.

Williams et al. (1970) suggested that autoclaving breast milk could have accounted for the poor fat absorption which they obtained when they fed this milk to term infants. Similarly, Widdowson (1974) also studied term infants after fresh breast milk had been pasteurised and lyophylised. However, an earlier study specifically designed to investigate the influence of various heat treatments and storage conditions upon the preterm infant's ability to absorb fat from human milk failed to show any effect (Soderhjelm, 1952). Fomon and Owen (1962) also failed to provide evidence of nutritional impairment of the protein in an autoclaved milkbased formula. Studies on growth are limited but they indicate a restricted weight gain when infants are fed heated human milk (Catel and Sager, 1960; Sager, 1960).

In this investigation, we considered that the limitations of using a small number of infants for the purpose of comparing the 3 milks were largely overcome by the design of the study. The most significant and consistent result to emerge was the better rate of fat absorption from the raw milk. The deleterious effect of heat treatment occurred at both the temperatures used, although it was greater in the boiled than the pasteurised milk. The difference in absorption could not have been secondary to the milk's fatty acid composition as each study used the same source of milk. The fatty acid configuration within the triglyceride molecule is also known to influence fat absorption (Tomarelli et al., 1968; Filer et al., 1970), but it is not certain if the configuration is altered by heat treatment alone, although heating may alter milk fat in other ways. 
For instance, boiling can result in a general fat loss owing to the formation of a surface skin and a deposit at the bottom of the container in which the milk is heated (Ashton, 1972). Also, the complex fat globule membrane is altered by heating with loss of membrane material (Loewenstein and Gould, 1954). This might have been expected to enhance rather than impede lipolysis. Similarly, the smaller fat intake during the boiled milk balance should improve the percentages in view of the negative correlation noted between fat intake and absorption.

Malabsorption of fat similar to that noted here has been widely reported in preterm infants (Davidson and Bauer, 1960; Zoula et al., 1966; Katz and Hamilton, 1974). Two major factors are held responsible - a deficiency of bile acids and also of pancreatic lipase. The intraluminal bile acid concentrations are frequently below the critical micellar concentration necessary for the solubilisation of the end products of lipolysis. This has been shown to correlate well with the degree of steatorrhoea in these babies (Lavy et al., 1971; Signer et al., 1974). Also from the evidence of pancreatic lipase noted during feeds (Norman et al., 1972), and the presence of unhydrolysed glycerides in the stools of term infants (Watkins et al., 1974), it appears that exocrine pancreatic function is similarly inadequate in early life. However, Zoppi et al. (1972) were able to demonstrate that preterm infants are able to secrete a considerable amount of pancreatic lipase in response to exogenous pancreozymin and secretin, although the levels were very low when compared with those secreted by older infants and children. They also noted that lipase production was not stimulated by diets containing a relatively large amount of fat when the amount of protein in the diet was small, a situation akin to that of feeding mature human milk.

The role of human milk lipases in the absorption of dietary fat has only recently received serious consideration (György, 1971; Castberg and Solberg, 1972). In particular, the bile-stimulated lipase has been shown to produce lipolytic activity equivalent to that of pancreatic lipase under conditions simulating those of the neonatal intestine (Hall, 1975; Hernell, 1975). Also such lipases are known to be heat labile (Hernell, 1975) with loss of lipolytic activity related to the degree of heat applied. As neither bile salt levels nor endogenous lipase production would be expected to alter in relation to the way in which the milks were processed, dietary lipase offers a possible explanation for the changes noted in fat absorption. This hypothesis is supported by the higher levels of free fatty acids present in the stools of milk triglycerides once ingested. In addition, there may have been a small contribution resulting from the increased levels of free fatty acids in the raw milk before feeding.

Good fat absorption is important for the preterm infant, both because of the high calorie content of fat and its role in brain development (Crawford, 1976). Also excess faecal loss may be associated with a loss of vitamin D and calcium (Widdowson, 1965; Southgate et al., 1969; Hanna et al., 1970). The development of osteoporosis and rickets in two of these infants suggests that their intake of both $\mathrm{Ca}$ and vitamin $\mathrm{D}$ was inadequate. This is not unexpected as the $\mathrm{Ca}$ content of human milk is known to be insufficient to allow for $\mathrm{Ca}$ accretion at a rate comparable to that in utero (Shaw, 1976). Also, as each infant was fed on boiled human milk both before and after the period of the balance studies, and the study demonstrated a positive correlation (correlation coefficient 0.647 ) between fat and calcium absorption, the steatorrhoea resulting from the boiled milk might have been expected to limit the infant's rate of $\mathrm{Ca}$ accretion. Our results do not suggest that feeding raw milk will improve this situation as, although 4 of the infants demonstrated improved $\mathrm{Ca}$ absorption from the raw milk, there was no significant difference for the whole group fed raw milk compared with those fed heated milks.

There is evidence suggestive of diminished $\mathrm{N}$ retention resulting from the boiled milk. This occurred without any such change in $\mathrm{N}$-absorption and parallels that noted by Royer (1973) in his study which used modified cows' milk. Heating will of course, denature the milk proteins and profoundly alter their electrophoretic pattern (Catel and Sager, 1960). In addition, heat treatment may involve the free amino groups of milk proteins and the aldehyde group of lactose in the Maillard reaction (Ellis, 1959). The protein-carbohydrate complex so formed, although possibly absorbed satisfactorily, is probably not incorporated within new cells. There is thus a resultant loss in the urine of potentially available nutrients derived from both the carbohydrate and protein component of the milk (Valle-Riestra and Barnes, 1970). This gives a possible explanation for the indication we have from this study that $\mathrm{N}$ retention is diminished when the milk is subjected to the more severe heat treatment.

The infants' weight gains were calculated for a period of a week for each milk and were related to the volumes of milk consumed. As breast milks vary in composition and only that fed during the period of the balance studies was analysed, it was not possible to relate weight gain to calorie intake. However, all milk came from pools of several donors and our previous analyses of such pools (Williamson et al., 1978), have shown only minor differences in composition. The greater weight 
gain noted when all infants were fed raw milk accords well with the balance study data. As fat accounts for almost half of the calorific value of human milk, the losses of fat which can occur during processing, feeding, and in the stool, are of critical importance to infants whose intake is otherwise limited. Also, if one accepts that milk lipases in raw milk complement the infant's own inadequate lipase production, this effect may well be more pronounced in infants who are studied soon after birth, at a time when endogenous lipase production is known to be lowest (Zoppi et al., 1972).

We are grateful for the assistance of the nurses, milk bank staff, and medical students working in the neonatal intensive care unit at King's College Hospital; to Mr J. H. Hewitt (Public Health Laboratory, Dulwich Hospital) for his work on the bacteriology of the milk samples; to Professor J. W. Scopes (St Thomas's Hospital) for allowing the study of an infant under his care; to Mrs Pamela Golding for her secretarial help; and to $\mathrm{Mr} \mathrm{K}$. Ryan for advice on statistics. S.W. held a Wates Research Fellowship.

\section{References}

Addy, D. P. (1976). Infant feeding: a current view. British Medical Journal, 1, 1268-1271.

Ashton, W. M. (1972). The components of milk, their nutritive value and the effects of processing: Part 2. Dairy Industries, 37, 602-611.

Bliss, C. M., Small, D. M., and Donaldson, R. M. (1971). The use of somication to eliminate sampling and storage errors in stool fat determinations (abstract). Clinical Research, 19, 387.

Castberg, H. B., and Solberg, P. (1972). Human milk lipase and the importance of milk lipases for the infants' digestion of fat. Meieriposten (Oslo) 61, 783-795.

Catel, V. W., and Sager, C. A. (1960). Weitere Studien über rohe und erhitzte Frauenmilch. Monatsschrift für Kinderheilkunde, 108, 37-45.

Crawford, M. A. (1976). Lipids and development of the human brain. Biochemical Society Transactions, 4, 231-233.

Davidson, M., and Bauer, C. H. (1960). Patterns of fat excretion in feces of premature infants fed various preparations of milk. Pediatrics, 25, 375-384.

Davies, D. P. (1977). Adequacy of expressed breast milk for early growth of preterm infants. Archives of Disease in Childhood, 52, 296-301.

Dubowitz, L. M., Dubowitz, V., and Goldberg, C. (1970). Clinical assessment of gestational age in the newborn infant. Journal of Pediatrics, 77, 1-10.

Ellis, G. P. (1959). The Maillard reaction. Advances in Carbohydrate Chemistry, 14, 63-134.

Filer, L. J., Jr, Mattson, F. M., and Fomon, S. J. (1970). Triglyceride configuration and fat absorption by the human infant. Journal of Nutrition, 99, 293-298.

Fomon, S. J., and Owen, G. M. (1962). Retention of nitrogen by normal full-term infants receiving an autoclaved formula. Pediatrics, 29, 1005-1011.
Fomon, S. J., Ziegler, E. E., and Vazquez, H. D. (1977). Human milk and the small premature infant. American Journal of Diseases of Children, 131, 463-467.

György, P. (1971). Biochemical aspects of human milk. American Journal of Clinical Nutrition, 24, 970-975.

Hall, B. (1975). Activation of human milk lipase. Biochemical Society Transactions, 3, 90-91.

Hanna, F. M., Navarrete, D. A., and Hsu, F. A. (1970). Calcium-fatty-acid absorption in term infants fed human milk and prepared formulas simulating human milk. Pediatrics, 45, 216-224.

Hernell, O. (1975). Human milk lipases. III. Physiological implications of the bile salt stimulated lipase. European Journal of Clinical Investigation, 5, 267-272.

Jelliffe, D. B. (1975). Unique properties of human milk: remarks on some recent developments. Journal of Reproductive Medicine, 14, 133-137.

Katz, L., and Hamilton, J. R. (1974). Fat absorption in infants of birthweight less than 1,300 gm. Journal of Pediatrics, 85, 608-614.

Lavy, U., Silverberg, M., and Davison, M. (1971). Role of bile acids in fat absorption in low birthweight infants (abstract). Pediatric Research, 5, 387.

Loewenstein, M., and Gould, I. A. (1954). The effect of heat on the chemical nature of the material absorbed on the milk fat globule. Journal of Dairy Science, 37, 644.

Lubchenco, L. O., Hansman, C., Dressler, M., and Boyd, E. (1963). Intrauterine growth as estimated from live-born birthweight data at 24 to 42 weeks of gestation. Pediatrics, 32, 793-800.

Norman, A., Strandvik, B., and Ojamäe, O. (1972). Bile acids and pancreatic enzymes during absorption in the newborn. Acta paediatrica Scandinavica, 61, 571-576.

O'Brien, D., Ibbott, F. A., and Rodgerson, D. O. (1968). Laboratory Manual of Pediatric Biochemical Techniques, fourth edition, pp. 238-240. Harper and Row: New York.

Royer, P. (1973). Bases metaboliques de l'utilisation des laits dits humanises. Pädiatrische Fortbildungskurse für die Praxis, 371, 15-25.

Sager, C. A. (1960). Further studies on raw preserved human milk with special reference to centrifugal sterilization (in German). Monatsschrift für Kinderheilkunde, 108, 119-120.

Shaw, J. C. L. (1976). Evidence for defective skeletal mineralization in low birthweight infants; the absorption of calcium and fat. Pediatrics, 57, 16-25.

Signer, E., Murphy, G. M., Edkins, S., and Anderson, C. M. (1974). Role of bile salts in fat malabsorption of premature infants. Archives of Disease in Childhood, 49, 174-180.

Soderhjelm, L. (1952). Fat absorption studies in children. I. Influence of heat treatment of milk on fat retention by premature infants. Acta paediatrica Scandinavica, 41, 207-221.

Southgate, D. A. T., Widdowson, E. M., Smits, B. J., Cooke, W. T., Walker, C. H. M., and Mathers, N. P. (1969). Absorption and excretion of calcium and fat by young infants. Lancet, 1, 487-489.

Stearns, G. (1939). The mineral metabolism of normal infants. Physiological Reviews, 19, 415-438.

Tomarelli, R. M., Meyer, B. J., Weaber, R. J., and Bernhart, F. W. (1968). Effect of positional distribution on the absorption of the fatty acids of human milk and infant formulas. Journal of Nutrition, 95, 583-590.

Valle-Riestra, J., and Barnes, R. H. (1970). Digestion of heat-damaged egg albumen by the rat. Journal of Nutrition, 100, 873-882.

Van de Kamer, J. H., ten Bokkel Huinink, H., and Weyers, H. A. (1949). Rapid method for the determination of fat in faeces. Journal of Biological Chemistry, 177, 347-355. 
Watkins, J. B., Bliss, C. M., Donaldson, R. M., Jr, and Lester, R. (1974). Characterisation of newborn fecal lipid. Pediatrics, 53, 511-515.

Widdowson, E. M. (1965). Absorption and excretion of fat, nitrogen, and minerals from 'filled' milks by babies one week old. Lancet, 2, 1099-1105.

Widdowson, E. M. (1974). Nutrition: Scientific Foundations of Paediatrics, pp. 44-55. Edited by J. A. Davis and J. Dobbing. Heinemann: London.

Williams, M. L., Rose, C. S., Morrow, G., Sloan, S. E., and Barness, L. A. (1970). Calcium and fat absorption in neonatal period. American Journal of Clinical Nutrition, 23, 1322-1330.

Williamson, S., Hewitt, J. H., Finucane, E., and Gamsu, H. R. (1978). Organisation of bank of raw and pasteurised human milk for neonatal intensive care. British Medical Journal, 1, 393-396.
Wootton, I. D. P. (1964). Microanalysis in Medical Biochemistry, fourth edition. Churchill: Edinburgh.

Zoppi, G., Andreotti, G., Pajno-Ferrara, F., Njai, D. M., and Gaburro, D. L. (1972). Exocrine pancreas function in premature and full-term neonates. Pediatric Research, 6, 880-886.

Zoula, J., Melichar, V., Novak, M., Hahn, P., and Koldovsky, O. (1966). Nitrogen and fat retention in premature infants fed breast milk, 'humanised' cow's milk, or half-skimmed cow's milk. Acta paediatricia Scandinavica, 55, 26-32.

Correspondence to Dr S. Williamson, Department of Child Health, King's College Hospital Medical School, Denmark Hill, London SE5 8RX. 